\title{
PLANNING CITY DEVELOPMENT DIRECTIONS \\ WITH THE APPLICATION OF SENTIMENT ANALYSIS
}

Dorota Jelonek ${ }^{a}$, Cezary Stępniak ${ }^{a}$, Tomasz Turek $^{a}$, Leszek Ziora ${ }^{a}$

\begin{abstract}
The aim of the article is to present a model of sentiment analysis tool application for planning directions of city development. The study presents a model of using sentiment analysis to build city development strategies as well as realization of projects related to it. The presented model is a part of a larger work on developing the concept of the Regional Spatial Business Community (RSBC). The RSBC is created on the basis of electronic communities built by stakeholders involved in the development of a given city. On the basis of surveys, a six-stage city development procedure is proposed. Using the aforementioned procedure, we describe potential data sources, the goals of sentiment analysis application and expected effects. Analyses of the applicability of sentiment analysis are made on the basis of observation of available tools. The obtained model is applicable; however, its implementation requires certain conditions to be met.
\end{abstract}

Keywords: Sentiment analysis, business analytics, city development, smart cities, e-government

JEL Classification: M10, O31, O32, O33

\section{Introduction}

Cities and communities are one of the elements of the administrative division of the state. They constitute an important component of the local government of a country. In Poland, cities and municipalities are the lowest level of government administration. Rationally acting municipalities strive to create a city development strategy based on the opinions of citizens and entities connected with a particular area - an example is Katowice 2030 (Podgórska-Rykała, 2018). Decisions taken by municipalities may have a significant

a Czestochowa University of Technology, Czestochowa, Poland

Email: dorota.jelonek@wz.pcz.pl, cezary.stepniak@wz.pcz.pl, tomasz.turek@wz.pcz.pl, leszek.ziora@wz.pcz.pl 
influence on the level and ways of inhabitants' lives. It is important to develop a long-term strategy for the development of a given municipality, and then take up appropriate ventures, which will remain in close connection with its implementation.

The crucial moment in building the strategy is adaptation of its principles. Taking into consideration the fact that municipal authorities are elected within a relatively small community, they should adjust their actions to meet the expectations of local communities to the highest possible degree. It means, among other things, the need for public consultation, persuasion about proposed strategic objectives and potential socio-economic-cultural ventures resulting from it; sometimes, it requires mediation between parties that represent different visions of the municipality development. For municipal authorities, it is essential to correctly diagnose attitudes and expectations of local residents before making a final decision (concerning strategy and then consistently to ventures or municipal investments undertaken). For this purpose, it is crucial to apply appropriate methods of public consultation and techniques of collecting and compiling opinions of entities connected with the particular region. An important role in decision-making processes is played by non-financial ratios (Skoczylas, 2008).

The paper takes up the problem of sentiment analysis, as a potential technology which may be used for data collection and analysis of various types of documents, opinions or attitudes which may constitute the basis for making adequate decisions. The presented discussion shows an environment in which decisions are made that concern the direction of the community development, potential investments, data sources which allow determining the residents' preferences, as well as models of sentiment analysis application. These considerations are based on research into potential investment needs done as part of environments organized in the Regional Business Spatial Community and analysis of applicability of sentiment analysis tools for the construction of the municipality's development strategy and reported investment needs.

The presented considerations lead to a proposal for a model of sentiment analysis application in modelling municipal development. The presented model was developed on the basis of two research projects. The first was a study of the possibilities of organization of a Regional Business Spatial Community in Czestochowa (Jelonek, 2013). Its effect was, among other things, to identify the types of stakeholders interested in participating in the proposed communities and in general participation in planning the city's development. However, for the purposes of elaborating the proposed model, it was indispensable to conduct further research. It was carried out in 47 communes of the Silesian Voivodeship. On its basis, a procedure for planning the development of communes, collected data sources, the possibilities of using sentiment analysis and assumed effects were defined. The results of the research conducted indicate that, 
as a part of planning the development of municipalities, it is formally possible to implement the proposed model, but in practice it may be necessary to overcome various types of barriers.

\section{Definition, Methods and Techniques of Sentiment Analysis}

The goal of sentiment analysis or opinion mining is "to discover people's opinions expressed in written language" (Farhadloo and Rolland, 2016). It is one of the fastestgrowing research areas (Mantyla et al., 2016, p.1), where novel approaches such as clustering-based sentiment analysis are developed ( $\mathrm{Li}$ and Liu, 2012). Liu provides a definition of sentiment analysis as "the field of study that analyses people's opinions, sentiments, evaluations, appraisals, attitudes, and emotions towards entities such as products, services, organizations, individuals, issues, events, topics, and their attributes" (Liu, 2012, p.7). Sentiment analysis is a part of text mining, natural language processing, computational linguistics, big data, business analytics and machine learning. Sentiment analysis allows for gathering and analysis of opinions concerning a particular product or service together with monitoring online feedback (Ziora, 2016, pp. 234-241) and its area of application may also include planning of possible municipal investments, where it may bring many benefits for the subjects which have applied such a solution.

As far as the categories of different methods and approaches to conducting the sentiment analysis are concerned, it is worth mentioning its division presented by Medhat et al. (2014), who divided sentiment analysis into two approaches, namely a machine learning and a lexicon-based approach. The lexicon-based approach may embrace a dictionary-based approach and a corpus-based approach, which is then subdivided into statistical and semantic analysis. The machine learning approach contains methods of supervised and unsupervised learning. Supervised learning includes such methods and techniques as neural networks, decision trees, support vector machines, rule-based and probabilistic classifiers such as naïve Bayes, Bayesian network and maximum entropy (Medhat et al., 2014). Maas et al. (2011) show that there exists the possibility to use "a mix of unsupervised and supervised techniques to learn word vectors capturing semantic term document information as well as rich sentiment content”. Agarwal and Mittal (2016, p.1) classify sentiment analysis according to its relation to the whole document (documentlevel), in relation to a particular sentence (sentence-level), and in relation to a particular aspect or feature (aspect-feature-level). Lula et al. (2016) underline that "opinion may refer to a product as a whole or its components and the attitude presented in the opinion is called overtones". Pang and Lee (2008, p. 2) present survey results where "among readers of online reviews of restaurants, hotels, and various services (e.g., travel agencies 
or doctors), between $73 \%$ and $87 \%$ report that reviews had a significant influence on their purchase and consumers report being willing to pay from $20 \%$ to $99 \%$ more for a 5 -star-rated item than a 4 -star-rated item".

\section{Areas of Sentiment Analysis Application}

Areas of sentiment analysis application may include economics, finance, marketing and politics. It may be used in finance by application of supervised learning, e.g., to "learn the association between polarity of financial news and key financial indicators" (Ahmad and Khurshid, 2011); in trade and sales, to gather opinions on, e.g., launching of new products on a market, proposed improvements to existing products and services, etc.. Practical examples of its application embrace assessment of utility of products and services, where products and services may be developed on the basis of opinion, shaping the image of organization or support to decision-making processes. The data sources for the purpose of analysis include: traditional media (TV, radio, press) social media, discussion forum posts, blogs and microblogs, YouTube comments, book and film review sites, etc.

According to SAS Institute solutions, the benefits of conducting such analyses include "automatic extraction of sentiment in real time or in a certain defined period of time, reports on patterns and commentators' reactions, identification of feedback sources, search and evaluation of internal and external content about a particular organization and competitors, identification of positive, negative, neutral and 'no sentiment' texts and thus improvement of the competitive position of a business organization" (SAS, 2016). Besides cities and communities, the target group of sentiment analysis beneficiaries may constitute chain stores, banks, financial institutions, distribution networks and non-profit organizations.

Estevez-Ortiz et al. (2016) showed the role of people's sentiment in social media towards smart cities and smart governance, where the authors conducted a "categorization of opinions and expressions in social networks, linked to entities, facts, and properties". They presented the interaction between the sentiments of society, internet opinions, and local governance. Their research included categories such as the environment, pollution, traffic and economy.

In the area of planning proposals for city development, both approaches of sentiment analysis, which are lexicon-based approaches and machine learning methods and techniques, may be applied. Sentiment analysis can be helpful in collecting all types of local opinions and, as a result, lead to administrative decisions in cities and municipalities. The same methods and techniques of analysis can be constantly improved similarly to the process of knowledge management which "realizes the principle of continuous improvement" (Zawiła-Niedźwiecki, 2015). 


\section{Research Methodology}

Planning development of cities and municipalities is a complex task. It is both a factor of time and a diversity of entities that can be involved. Sentiment analysis has its own specificities and can be applied to specific types of activities, that is, generally for the processing of qualitative data. Qualitative data appear in various forms, come from various sources and can be used at all stages of strategic planning (types of data collected in municipalities are presented, e.g., by Madej, 2018).

The construction of the present study refers to the interconnection of two issues: the elaboration and implementation of a municipal development strategy and the search for new applications for sentiment analysis tools. The first issue was identified both practically and theoretically. The practical identification resulted from the study authors' social activity, which allowed them to get acquainted with practical aspects of local governments' activities. The concept of the construction of the RSBC (Jelonek et al., 2013) was developed on this basis. The concept mentioned above was developed, among others (Stępniak, Turek, 2014; Stępniak, Turek, 2015). Thanks to the work on this concept, we identified the types of stakeholders interested in participating in planning the city's improvement. Initially, the scope of information resources which could be used in the course of improving the strategy and its subsequent implementation was also examined.

The second of the discussed issues is potential new applications of SA tools. Based on the economic and humanistic concept of local government management space (presented in Kożuch, 2016), it was pointed out that the popularity of local leaders and the inhabitants' standard of living does not depend solely on good economic results. Therefore, not only economic data, usually presented in the form of quantitative data, but also data related to various social, cultural and other issues, which are usually in the form of qualitative data, are important for community management. Based on literature studies and meetings held at the SAS Institute, a concept of using SA tools in local government units appeared.

The basic research assumption was that the application of SA tools requires access to appropriate information resources. A system of activities (presented in the next section of the study) was developed for the purpose of elaboration and implementation of development strategies. It became important for the activities mentioned above to determine what information is useful and what its sources may be. At the same time, an attempt was made to examine the knowledge of SA tools among local governments. The above issues were included in a questionnaire developed for the research purposes. Then the research sample was selected. For this purpose, 47 self-government units were chosen, 
covering various types of communes (i.e., cities with county rights, cities, urban-rural and rural communes). Although all the communes belong to the same voivodeship, they are historically and culturally diversified and cover different types of communities: industrial, industrial and service communes, bedrooms of larger towns, tourist and agricultural ones. The surveyed communes also differed in terms of economic development.

The research was preliminary and exploratory. The aim was to determine whether similar principles of strategy development and implementation are applied in communes, how collected information is used for strategic purposes and what is the knowledge about SA tools (Jelonek et al., 2019).

On the basis of questionnaire surveys carried out by telephone, and in some cases direct talks with commune authorities, attempts were made to explore the potential of using sentiment analysis for the purpose of planning improvement of municipalities. The studies drew attention to the procedures for implementation of municipal improvement planning, and also the collected text and multimedia resources, the needs for their processing, as well as the types of entities that are or may be involved in these activities. The model of using sentiment analysis was developed on the basis of the results obtained.

The research survey embraced 47 units because some kind of repetitiveness appeared at some point while conducting subsequent interviews. Although communes showed significant diversity in management principles and the importance of the need for the commune's development strategy, in effect it came down to specific schemes. Usually, more or less formalised rules of gathering information, cooperation with stakeholders and technology were applied, depending on the level of the commune's development and its location and wealth. Unfortunately, a very low level of knowledge of the possibility to use SA tools emerged in the course of the research. This situation was justified by the demonstrated level of information needs and financial resources that could be used for investments in IT tools.

The data obtained during the survey were descriptive and reflected the current state of affairs in the particular communes. Respondents presented the principles of creating strategies in the given commune, indicated which data are subject to registration and whether it is incidental or formalised, and at the end of the survey the respondents were asked whether SA tools are used in the commune or whether these tools are known to the commune management board.

The research results, supported by the existing knowledge of the functioning of local governments, enabled the development of a model of SA tool application to support planning city development directions. The model mentioned above includes the scope of potentially supported activities, interested stakeholders, data sources and methods of SA tool application. The model proposed in the study has two purposes. On the one hand, 
it reflects the current situation of communes in the discussed issues, and on the other hand, it is a model that communes could pursue if they became more interested in qualitative data that can be used for commune management purposes.

\section{Role of Investments in Shaping Directions of City Development}

Shaping directions of municipalities and city development depends on many factors. Modelling the development should proceed from the whole to the parts. The individual steps form the following system:

1. Building a city (community) strategy;

2. Creation of an adequate development plan;

3. Investment planning or searching for investors;

4. Public consultation in the scope of planned investments;

5. Realization of investment; and

6. Modification and control activities.

However, the practice of city management is more complicated. Firstly, the construction of a strategy requires taking into account the existing socio-economic base, as well as the traditions and cultural factors specific to the particular area. It is a case of creating urban or municipal space (Santos Cruz, 2018) Secondly, various local interest groups may have an influence on the strategy created and they do not always have convergent interests. Then, the management board of the particular unit will be responsible for further mediation, if any such possibility occurs. In extreme cases, accepted strategic objectives may result in the formation of opposition to the board of the entity and to investments undertaken. Thirdly, the boards of municipalities do not always see the need for the development of a full municipal strategy. We raise an issue concerning mainly small units, where the municipal authorities are busy solving current residents' specific problems and do not see the need to develop strategic objectives at the moment. Currently, the development of the strategy is limited to elaboration of documentation required by government regulations or financial institutions which will be required to apply for loans or credit and credit capacity has to be confirmed in order to undertake the planned projects.

As a result, the urban management practice can very simply be limited to planning own investments and supervision of others made by external entities. Despite this, it is important for city boards to build positive sentiments in relation to the accepted strategy, as well as to investments made. This is done at every stage of the investment project, starting from the conception phase and lasting in the ongoing operation of the venture. 
Building a positive image around investments being undertaken and realized as well as functioning ventures typically causes generation of various types of documents, reports, opinions, articles and other comments. They come from different sources, may have different substantive weight and express different attitudes to the same issues and represent opinions of many entities. Sources created can make a direct description of the individual investments or ventures or refer to them indirectly, as one of the issues in a broader context. For the purpose of sentiment analysis in the retrieval and analysis of collected data, the following issues should be taken into consideration:

- In what context the document appeared;

- To which investments or projects it refers;

- Is there a direct or indirect reference;

- Who is the author, or whose opinion is expressed;

- Is it a positive, negative, or neutral opinion; and

- The text refers to the whole investment or it only raises selected issues.

The above issues should be examined at each stage of the modelling of a development strategy of the particular municipality (city). However, one should be aware that the possibility of using the results of sentiment analysis generates different consequences for different stages of decision-making. As part of steps 1-4, the possibilities of withdrawal from the planned activities can be considered. In further investment stages, or after completion, mainly the possibilities of modifying the rules or effects of the venture's activity can be basically considered. Therefore, the necessity of conducting sentiment analysis at the earliest possible stage seems to be essential and potential opinion-creating factors should be stirred to action as extensively and early as possible. It may give a chance to convince potential opponents, or the investment plans may be corrected before starting a particular investment.

\section{Types of Entities Involved in Shaping Directions of City Development}

The development of cities and regions depends on various types of cooperation. Different goals and objectives are stated for every type of entity. Proper coordination of activities can allow creation of a city/region that has features of attractiveness, which will bring benefits for internal stakeholders and for external ones it may constitute a factor conducive to cooperation, influx or migration.

The main groups of subjects shaping the image of the city/region are (compare, e.g., Musioł-Urbańczyk, 2016): 
- residents,

- $\quad$ entities of public administration (government and local government),

- $\quad$ commercial companies (role in local development presented, e.g., in Contreras, 2018),

- municipal companies,

- utility companies (water, electricity, gas, communications, television, Internet),

- educational institutions and universities,

- hospitals and health care facilities,

- local media: press, radio and television.

In quantitative terms, residents are the largest group among these entities. Residents determine the potential of the city and the region to a great extent. On the other hand, their degree of involvement depends on the conditions and cooperation with other entities, in particular public administration. Residents as beneficiaries of a number of initiatives constitute an inexhaustible source of ideas and initiatives. The role of citizens has been recognized for a long time, and since 2012, the concept of "smart cities" has been used, of which Boyd Cohen is the promoter (https://www.fastcoexist.com/1680538/whatexactly-is-a-smart-city). The key characteristic of a smart city is presented in Caird (2018).

Public administration bodies, especially local governments, are entities whose job is to coordinate efforts to make cities and regions as attractive as possible for the development of citizens, business, and science. The role of citizens is increasingly noticed. The latest generation of smart cities - defined as 3.0 - means opening up of local governments to proactive citizens' attitudes in shaping their further development. The local authorities assume the role of creating space and opportunities for potential residents. This applies to both encouraging them to use modern technology and enabling them to create their own ideas (Smart City, 2016, p.16). Similar opinions can be found among city mayors. Mayor of Poznań Jacek Jaśkowiak notes that "we widely use surveys which allow us to get to know the expectations and opinions of various groups of inhabitants. The competitiveness of the city is measured today not only in economic indicators, but also in more difficult-tomeasure feelings of the residents, and their level of satisfaction" (Smart City, 2016, p.17).

Besides city authorities and inhabitants, companies are an extremely important group. They may include typical commercial companies (with their own business activity), municipal companies (owned by local governments, whose most common task is provision of services for residents) and utilities (water, gas, electricity, etc.). The role of enterprises has been characterized by, e.g., Jan Olbrycht, Member of the European Parliament: "The city is not only the local authorities and administration, but everyone who creates it, first of all residents and businesses" (http://janolbrycht.pl, 2017). Creating favourable conditions for business is fundamental for the work of many local governments. 
It manifests in the creation of economic zones, portals bringing together investors, etc. The formation of new businesses and investments in emerging workplaces mainly affects the numbers of jobs in the region, which in turn improves the public mood. Their behaviours are strongly connected with business information spread in local community and social networks (for instance as RSBC) (Zhao, 2018).

Cities and regions relate strongly to education and science. The education system provides development of children's and teenagers' knowledge and skills and integrates residents. Universities provide further education for the region's residents and potential influx of students from other locations. An important role of universities is also cooperation with the business. It allows achievement of mutual benefits. On the one hand, companies have access to modern and innovative technical ideas, and on the other hand, universities are a place for the application of research.

The standard of living in the city/region is also determined by the level and availability of health services. The health care development strategy is in the responsibilities of local governments at all levels. Local governments play the role of organizers in this area. It is worth noting that while improving the development strategy in the field of health care, apart from the creation of appropriate medical units, it is also possible to include issues of sport, physical culture and recreation, which may additionally affect the quality of life of the residents. The development of cities and regions is also dependent on the local media. Its task is not only to discuss and describe the current status. The media fulfil a creative function. Based on reviews and analyses, they can identify and publicize initiatives to promote regions and educate.

\section{Data Sources Generated in Environments Affecting Development of Cities}

The basic condition for the use of data and opinions collected using sentiment analysis tools is their digital form. Residents, authorities, enterprises and other entities involved in shaping the development of the city create a specific community. The cohesive element in this community is its inhabited geographic area (city, region). Individual entities are able to express their opinions and judgements related to the functioning in the framework of business-community relationships. In the era of Web 2.0, and the development of Web 3.0 the expressed opinions take the digital form and are often publicly available on the Internet. The growing importance of CloudComputing technology in local governments can be helpful (Hauke, 2018). This allows processing using sentiment analysis. The main sources of data in this area are: social media, comment systems, surveys and forms, e-mail, local media and online forums. 
Social media are the most important source of data containing opinions of citizens and other entities within local communities. In fact, every social networking site (Facebook, Tweeter, YouTube, etc.) allows keeping private accounts (for ordinary users) and public accounts (for companies and institutions). As a part of public accounts, Internet users can leave comments, give opinions and initiate discussions. It is possible to organize public discussions of experts on especially important investments for the municipal space (Ewing, 2009). Within their own initiatives, residents can also create online communities on different topics (road construction, nursery renovation, etc.) within the scope of geographical areas.

Data for sentiment analysis can also be retrieved from comment systems and entries on the websites of government authorities, companies and institutions functioning within the same city/region.

It is relatively easy to examine opinions using all kinds of surveys and forms. They can be submitted for completion to residents as well as representatives during or after accomplishment of a formal case. Surveys and forms have a fixed structure and format of fields, which is why opinions are often expressed in a quantitative way. An example of a survey using forms is the electronic voting systems for participatory budgets in many Polish cities.

Automatic analysis of opinions can also be conducted by scanning the words and phrases contained in e-mail. E-mail systems at the server side can create reports, which can then be processed by sentiment analysis tools.

Local media, press, radio and television, because of their mission, try to raise most of the key issues for the region. By publishing articles and reports they create opinions, and often stimulate discussion, which usually moves on to social networks and forums.

The development of ICT means that the boundaries between these sources are blurred. It is difficult to point out where one of the specified data sources begins, and where another ends. In addition, new technological solutions are constantly created, including mobile applications and other areas of opinion exchange concerning the situation in the community. If the opinion is digitized, it becomes a potential source of data for sentiment analysis.

The results of analyses can serve as a basis for decision-making in the area of urban and regional development. Listening to residents' opinions often gives a clear idea concerning their needs, shortcomings, or necessary investments. Opinions expressed by businesses show what barriers limit enterprise development. Their analysis allows creation of a suitable environment for new investments and activities. The generated data might then be processed by applying big data solutions (Jelonek et al., 2018). 


\section{Rules of Sentiment Analysis Application}

Sentiment analysis is a relatively new technology, where tools on the Polish market are in a novelty stage and where their application means being a leader in innovation. Application of these tools may be determined by many factors. They can embrace, e.g.,

- availability of appropriate tools,

- knowledge concerning possibilities of their application,

- local government's policy of public consultation,

- access to relevant data sources,

- access to relevant sentiment analysis tools, and

- existing vision of application areas of these tools.

It can therefore be assumed that application of sentiment analysis tools depends on four groups of factors: organizational, information, technology and economics. The fact is that different tools can be applied for various stages of modelling development of municipalities. This involves a change in the purpose of research goals within the individual stages. As a result, different goals can be distinguished for the next stages and tools adequate to these can be applied. A description of proposed solutions is presented in Table 1.

The proposed model is the result of the authors' research contacts with representatives of local governments, cities and municipalities in order to create RSBC aimed, among other things, at supporting regional development. Practical application of sentiment analysis tools in the context of this subject depends on the management boards of particular municipalities (their needs, financial resources, staff competence, as well as companies functioning in the area). 
Table 1: Model of sentiment analysis application in modelling development of a municipality

\begin{tabular}{|c|c|c|c|}
\hline Stage & SA goals & $\begin{array}{l}\text { Data sources and } \\
\text { proposed tools }\end{array}$ & Expected effects \\
\hline $\begin{array}{l}1 . \\
\text { Strategy } \\
\text { develop- } \\
\text { ment } \\
\text { (creation) }\end{array}$ & $\begin{array}{l}\text { Analysis of reported needs } \\
\text { of residents. Gathering } \\
\text { residents' opinions about } \\
\text { the vision of the future } \\
\text { of the community. } \\
\text { Polarization of interest } \\
\text { groups }\end{array}$ & $\begin{array}{l}\text { Social media, Internet } \\
\text { portals and sites, } \\
\text { discussion boards and } \\
\text { blogs. } \\
\text { Lexicon-based } \\
\text { approach, machine } \\
\text { learning methods } \\
\text { Big data solutions }\end{array}$ & $\begin{array}{l}\text { Getting to know people's } \\
\text { views concerning the status } \\
\text { of the community, directions of its } \\
\text { development, existing socio- } \\
\text { economic needs and infrastructure. } \\
\text { Determination of existing interest } \\
\text { groups. Identification of existing } \\
\text { antagonisms and their causes. }\end{array}$ \\
\hline $\begin{array}{l}2 . \\
\text { Creation } \\
\text { of develop- } \\
\text { ment plan }\end{array}$ & $\begin{array}{l}\text { Collecting residents' } \\
\text { opinions about urban zones } \\
\text { created. Polarization of local } \\
\text { interest groups (e.g., within } \\
\text { the district). }\end{array}$ & $\begin{array}{l}\text { Social media, Internet } \\
\text { portals and sites, } \\
\text { discussion boards. } \\
\text { Lexicon-based } \\
\text { approach, machine } \\
\text { learning methods }\end{array}$ & $\begin{array}{l}\text { Identification of local residents' } \\
\text { expectations regarding } \\
\text { the development plans } \\
\text { of individual districts (villages). } \\
\text { Determining interest groups. } \\
\text { Identifying causes of antagonism } \\
\text { occurring in a given district } \\
\text { (village). }\end{array}$ \\
\hline $\begin{array}{l}3 . \\
\text { Investment } \\
\text { planning }\end{array}$ & $\begin{array}{l}\text { Search for potential investors. } \\
\text { Assessment of planned } \\
\text { investments by residents. } \\
\text { Opinions concerning } \\
\text { opportunities and threats } \\
\text { connected with planned } \\
\text { investments. }\end{array}$ & $\begin{array}{l}\text { Social media, Internet } \\
\text { portals and sites, } \\
\text { discussion boards. } \\
\text { Lexicon-based } \\
\text { approach, machine } \\
\text { learning methods }\end{array}$ & $\begin{array}{l}\text { Searching for potential investors. } \\
\text { Social assessment of proposed } \\
\text { investments. Identification } \\
\text { of interest groups. Identification } \\
\text { of real and potential opportunities } \\
\text { and threats arising from planned } \\
\text { investments. }\end{array}$ \\
\hline $\begin{array}{l}4 . \\
\text { Public } \\
\text { consulta- } \\
\text { tion }\end{array}$ & $\begin{array}{l}\text { Collecting residents' } \\
\text { opinions about the state } \\
\text { of the community, residents' } \\
\text { needs, planned and realized } \\
\text { investments. Identification } \\
\text { of antagonisms. Assessment } \\
\text { of activities undertaken } \\
\text { by the municipality } \\
\text { management. }\end{array}$ & $\begin{array}{l}\text { Social media, Internet } \\
\text { portals and sites, } \\
\text { discussion boards. } \\
\text { Lexicon-based } \\
\text { approach, machine } \\
\text { learning methods, } \\
\text { discussion boards }\end{array}$ & $\begin{array}{l}\text { Identification of social needs. Social } \\
\text { assessment of activities undertaken } \\
\text { by the municipality management. } \\
\text { Identification of interest groups. }\end{array}$ \\
\hline $\begin{array}{l}5 . \\
\text { Realization } \\
\text { of invest- } \\
\text { ment }\end{array}$ & $\begin{array}{l}\text { Collecting opinions about } \\
\text { the course of investment. } \\
\text { Opinions concerning } \\
\text { opportunities and threats } \\
\text { connected with realized } \\
\text { investments. Survey } \\
\text { on antagonisms arising from } \\
\text { the realization of investments. }\end{array}$ & $\begin{array}{l}\text { Social media, Internet } \\
\text { portals and sites, } \\
\text { discussion boards. } \\
\text { Lexicon-based } \\
\text { approach, machine } \\
\text { learning methods }\end{array}$ & $\begin{array}{l}\text { Social assessment of effects } \\
\text { of realized investments. Perception } \\
\text { of investors by residents. } \\
\text { Identification of potential } \\
\text { threats and conflicts arising from } \\
\text { implementation of investment and } \\
\text { functionality of future venture. }\end{array}$ \\
\hline $\begin{array}{l}\text { 6. Effects } \\
\text { control }\end{array}$ & $\begin{array}{l}\text { Social assessment } \\
\text { of venture undertaken. } \\
\text { Analysis of the impact } \\
\text { of the investment } \\
\text { on the municipality } \\
\text { development. Search } \\
\text { for or solving problems } \\
\text { arising from investment } \\
\text { implementation. }\end{array}$ & $\begin{array}{l}\text { Social media, Internet } \\
\text { portals and sites, } \\
\text { discussion boards. } \\
\text { Lexicon-based } \\
\text { approach, machine } \\
\text { learning methods }\end{array}$ & $\begin{array}{l}\text { Social assessment of venture } \\
\text { functioning. Examination } \\
\text { of the level of local identification } \\
\text { with particular venture. Assessment } \\
\text { of community board activities. } \\
\text { Identification of potential threats. } \\
\text { Search for proposals for new } \\
\text { ventures. }\end{array}$ \\
\hline
\end{tabular}

Source: Authors' own study 


\section{Conclusion}

The paper presents the basic aspects of sentiment analysis application in building a strategy for the development of regions and cities. Preliminary discussions with local administration staff were conducted in order to determine further work on this subject. The pilot study included 47 units in 6 counties in the Silesian Voivodeship. Interviews were conducted with persons responsible for strategy development and investments in the cities and the IT departments who have an access to data stored in the IT systems, e-mails and social media. Officials agree that opinions expressed by both residents and business representatives are very important for the authorities. In principle, any initiative, investment or activity are directed by the articulated needs. The needs and opinions are often contradictory. In such a situation, it is necessary to conduct detailed analysis and debate.

The research results obtained allowed us to identify the current situation in terms of the need to build a strategy for the development of communes and the possibility to use SA tools for this purpose. The research showed that management boards in the majority of communes are mainly involved in solving local communities' current problems. The analysis of selected commune development strategies (official documents) indicates that the aforementioned documents are prepared for a relatively short time horizon, usually covering 5 to 10 years. To a large extent it is related to the management cadence. It seems more important for communes to issue current administrative decisions than to prepare long-term development plans.

In the light of the above, the issues of qualitative data collection are being pushed back and therefore it is likely that the knowledge of SA tools is relatively low. It should be noted, however, that the majority of respondents were interested in obtaining more knowledge concerning the tools mentioned above. Therefore, apart from the research results, the research also had a promotional and educational effect. Other problems may include financial and organisational issues. So far, budgets of small communes in particular do not provide for sufficient funds to purchase SA tool licenses. Apart from that, there is also a question of establishing appropriate organizational units that would be able to handle these tools. Therefore, some respondents said that they would wait for the tools to become more popular and thus cheaper to use.

The model presented in the paper is a product of the research findings and the authors' knowledge concerning both the creation and implementation of commune development strategies and the possibilities of using SA tools. It can be treated as a kind of roadmap for both development and implementation of commune strategies and the use of SA tools for this purpose. Of course, its shape may be modified along with the development of the discussed technology. 


\section{References}

Agarwal B., Mittal N. (2016) Prominent Feature Extraction for Sentiment Analysis.

Springer. Socio-Affective Computing, volume 2. Switzerland, p.1, https://doi. org/10.1007/978-3-319-25343-5

Ahmad, Khurshid. (ed.). (2011) Affective Computing and Sentiment Analysis. Emotion, metaphor and terminology. Springer, Dublin, https://doi.org/10.1007/978-94-007-1757-2

Caird S.P., Hallett S.H. (2018) Towards evaluation design for smart city development. Journal of Urban Design, DOI: 10.1080/13574809.2018.1469402

Contreras M. (2018) Family Organizations and Their Contribution to Local Development in the Arenitas Fishing Community. In Przedsiębiorczość i zarządzanie. Wydawnictwo SAN. Tom XIX, Zeszyt 7. Część II, ss. 23 -36, ISSN 2543-8190.

Estevez-Ortiz F., Garcia-Jimenez A., Glosekotter P.: An application of people's sentiment from social media to smart cities. El profesional de la información, 2016, noviembre-diciembre, v. 25, n. 6. elSSN: 1699-2407, https://doi.org/10.3145/epi.2016.nov.02

Ewing R. Handz S. (2009) Measuring the Unmeasurable: Urban Design Qualities Related to Walkability. Journal of Urban Design Volume 14, 2009 - Issue 1. pp. 65-84.

DOI: https://doi.org/10.1080/13574800802451155.

Farhadloo M., Rolland E. (2016), Fundamentals of Sentiment Analysis and Its Applications In: W. Pedrycz, S.-M. Chen (eds.): Sentiment Analysis and Ontology Engineering, Studies in Computational Intelligence 639, Springer International Publishing, Switzerland, https://doi.org/10.1007/978-3-319-30319-2_1

Fast Company (2018). https://www.fastcoexist.com/1680538/what-exactly-is-a-smart-city Accessed January 2018

Hauke K. (2018) Model przetwarzania danych w chmurze obliczeniowej na przykładzie gminy. In Przedsiębiorstwo we współczesnej gospodarce - teoria i praktyka, 2018, nr 2, s. 79-92, ISSN 2084-6495. DOI: http://dx.doi.org/10.19253/reme.2018.0.006.

Jelonek D., Mesjasz-Lech A., Stępniak C., Turek T., Ziora L.: (2019) Potential Data Sources for Sentiment Analysis Tools for Municipal Management Based on Empirical Research. [in:] Arai K., Bhatia R. (Eds.): Advances in Information and Communication: Proceedings of the 2019 FICC Conference. Springer Nature Switzerland AG 2020,pp. 708-725

Jelonek D., Stępniak C., Turek T. (2013) The Concept of Building Regional Business Spatial Community, In ICETE 2013 10th International Joint Conference on e-Business and Telecommunications. Proceedings, 29-31 July 2013, Reykjavik, Iceland 2013, s.83-90.

Jelonek D., Stępniak C., Ziora L. (2018) The Meaning of Big Data in the Support of Managerial Decisions in Contemporary Organizations: Review of Selected Research. Proceedings of 2018 Future of Information and Communication Conference, Singapore. IEEE New York 2018, pp. 195-198

Kożuch B. (2016), Współczesne perspektywy rozwiq̨zywania problemów zarządzania publicznego. In Zarządzanie i finanse Journal of Management and Finance. Vol. 14, no. $2 / 2 / 2016$ s. $167-178$. 
Li G., Liu F.: Application of a clustering method on sentiment analysis. Journal of Information Science. Sage Journals: http://journals.sagepub.com/doi/ abs/10.1177/0165551511432670, https://doi.org/10.1177/0165551511432670

Liu B. (2012), Sentiment Analysis and Opinion Mining. Morgan \& Claypool Publishers 2012. https://www.cs.uic.edu/ liub/FBS/SentimentAnalysis-and-OpinionMining.pdf

Lula P., Wójcik K., Tuchowski J. (2016), Analiza wydźwięku polskojęzycznych opinii konsumenckich ukierunkowanych na cechy produktu. Prace Naukowe Uniwersytetu Ekonomicznego we Wrocławiu nr 427, Wrocław DOI: 10.15611/pn.2016.427.16

Maas A.L., Daly R.E., Pham P.T., Huang D., Ng A.Y., Potts Ch. (2011). Learning word vectors for sentiment analysis. In Proceedings of the 49th Annual Meeting of the Association for Computational Linguistics: Human Language Technologies - Volume 1 (HLT'11), Vol. 1. Association for Computational Linguistics, Stroudsburg, PA, USA, 142-150.

Madej J., Widlak M. (2018) E-usługi w wybranych gminach województwa małopolskiego. In Nierówności Społeczne a Wzrost Gospodarczy, nr 53 (1/2018) pp. 340-350. DOI: 10.15584/nsawg.2018.1.29 ISSN 1898-5084

Mantyla M., Graziotin D., Kuutila M.: The Evolution of Sentiment Analysis - A Review of Research Topics, Venues, and Top Cited Papers. Computer Science Review 27, February 2018, https://doi.org/10.1016/j.cosrev.2017.10.002

Medhat W. (2014), Hassan A., Korashy H.: Sentiment analysis algorithms and applications: A survey. Ain Shams Engineering Journal. http://www.sciencedirect.com/science/article/ pii/S2090447914000550, https://doi.org/10.1016/j.asej.2014.04.011.

Musioł-Urbańczyk A., Sorychta-Wojsczyk B. (2016) Analiza procesu formułowania strategii rozwoju w miastach na prawach powiatu województwa śląskiego. In Zeszyty Naukowe Uniwersytetu Przyrodniczo-Humanistycznego, seria Administracja i Zarządzanie Issue-No 109, pp. 35-45.

Olbrycht, J. (2018). http://janolbrycht.pl/olbrycht-rozwoj-miast-zalezy-wladz-tych-wszystkichktorzy-je-tworza - Accessed January 2018.

Pang B., Lee L. (2008) Opinion Mining and Sentiment Analysis. Foundations and Trends in Information. Retrieval Vol. 2, Nos. 1-2 (2008) 1-135, p.2, https://doi. org/10.1561/1500000011

Podgórska-Rykała J. (2018) Change or Continuation? Long-Term City Management on the Example of Local Development Strategy of Katowice. Zmiana czy kontynuacja? Zarządzanie miastem w perspektywie długofalowej na przykładzie strategii rozwoju lokalnego. In Zeszyty Naukowe Wyższej Szkoły Humanitas. Zarządzanie, 2018, nr 2, s. 181-198, bibliogr. 30 poz. DOI: 10.5604/01.3001.0012.2047

Santos Cruz S., Roskamm N., Charalambous N. (2018) Inquiries into public space practices, meanings and values. Journal of Urban Design Volume 23, 2018 - Issue 6: Theme issue: Becoming Local. pp. 797-802. DOI: https://doi.org/10.1080/13574809.2018.1525289 
SAS sentiment analysis. Align with your customers' desires. http://www.sas.com/en_us/ software/analytics/sentiment-analysis.html [Retrieved January 2017]

Skoczylas W. (2008) Typologia wskaźników niefinansowych w badaniach analitycznych. In Studia i Prace Wydziału Nauk Ekonomicznych i Zarządzania Uniwersytet Szczeciński, 2008, nr 1, s. 177-187, ISSN 1899-2382.

"Smart City" dodatek do "Przeglądu Komunalnego" nr 9/2016, s. 16.

Stępniak C., Turek T.: Integration of Spatial Information Resources on the Example of Utility Companies in Częstochowa Region. In Online Journal of Applied Knowledge Management. Vol. 2, Issue 2, Knowledge Management Conference. Blagoevgrad, Bulgaria, June 25-28 2014. s. 97-108.

Stępniak C., Turek T., Levels of the Use of Electronic Communities in the Management of Regions In Preprints of the Federated Conference on Computer Science and Information Systems pp. 1567-1572. Łódź 13-16.09.2015.

Zawiła-Niedźwiecki J.: Structuring knowledge management - classical theory, strategic initiation and operational knowledge management (part1). Foundations of Management, Vol. 7 (2015), ISSN 2080-7279. DOI: 10.1515/fman-2015-0041

Zhao N., Cheng X., Guo X. (2018) Impact of information spread and investment behavior on the diffusion of internet investment products. Physica A: Statistical Mechanics and its Applications. Volume 512, 15 December 2018, Pages 427-436. https://doi.org/10.1016/j. physa.2018.08.075

Ziora L.: The Sentiment Analysis as a Tool of Business Analytics in Contemporary Organizations. Studia Ekonomiczne. Zeszyty Naukowe Uniwersytetu Ekonomicznego w Katowicach nr 281, Katowice 2016, pp. 234-241 